\title{
Andreas Fickers
}

'Politique de la grandeur' versus 'Made in Germany'. Politische Kulturgeschichte der Technik am Beispiel der PAL-SECAM-Kontroverse

München (R. Oldenbourg Verlag) 2007, 436 p., $€$ 49,80, ISBN 978348658 I782

In zijn in 2007 verschenen boek 'Politique de grandeur' versus 'Made in Germany' gaat de Maastrichtse techniek- en mediahistoricus Andreas Fickers in op de vraag waarom de ontwikkeling van een uniforme Europese standaard voor kleurentelevisies mislukte. Met de beantwoording van die vraag wil Fickers een bijdrage leveren aan de politieke cultuurgeschiedenis van techniek waarin techniekontwikkeling is verweven met politiek, economie en cultuur. Hiertoe combineert hij een multi-disciplinaire benadering met een multi-level benadering. Gerelateerde techniek-, economisch-, politiek- en cultuurhistorische vragen zijn daarbij gericht op de analyse van actorstrategieën in het standaardiseringsproces. De actorstrategieën worden gepositioneerd binnen drie domeinen, contexten of 'terrains': techniek, industrie en politiek op zowel nationaal als transnationaal niveau. Tezamen moeten vragen en contexten optellen tot een complete en meerdimensionale analyse.

Centraal in het boek staat de concurrentie tussen de Franse kleurentelevisiestandaard SECAM (Sequentiel Couleur a Memoire) en de Duitse kleurentelevisiestandaard PAL (Phase Alternating Line). De ontwikkeling van en de concurrentie tussen die nationale standaarden wordt geplaatst in een brede meerlagige nationale en internationale context. Van belang is daarbij de rol van Amerika. In de politiek-ideologische context van de Franse 'Politique de la grandeur' en de Duitse 'Soziale Marktwirtschaft' baseerden Duitse en Franse actoren zich op verschillende percepties over de rol van Amerika en de rol van de Amerikaanse kleurentelevisiestandaard NTSC (National Television System Committee). Voor de Fransen was 'Amerika' een concurrent en een bedreiging, voor Duitsland een concurrent en een partner. Vanuit die optieken werd de in I953 tot stand gekomen NTSC-standaard door zowel Franse als Duitse 
actoren gebuikt als basis voor eigen R\&D werk, waarbij de standaard werd aangepast aan nationale omstandigheden en eisen. Op basis van Frans-Duitse samenwerking konden de Duitse actoren bovendien voortborduren op het Franse SECAM systeem.

Omdat de via 'conservatieve innovatie' verkregen standaarden kwalitatief weinig van elkaar verschilden, ontstonden er concurrerende Duitse en Franse ambities om de eigen standaard tot Europese standaard te verheffen. De brede Europese consensus om in vroegtijdige fase van techniekontwikkeling te komen tot een Europese standaard voor kleurentelevisie was gebaseerd op de langdurige en moeizame totstandkoming van Europese standaarden voor zwart-wit televisie.

Fickers maakt aannemelijk dat de drie (NTSC, SECAM en PAL) standaarden kwalitatief niet veel verschilden en laat op overtuigende wijze zien hoe niet-technische factoren als marketing, system building en (politiek economische) alliantievorming van cruciaal belang waren in het standaardisatieproces. Belangrijke factor daarin was de politiek-economische context van beide landen. Domineerden in Duitsland strategisch-economische overwegingen van groei en expansie, in Frankrijk domineerden industriepolitieke belangen van modernisering en industriële protectie. Bovendien had de Franse overheid een directe invloed op de technische ontwikkeling, terwijl de directe invloed van de federale Duitse overheid beperkt was. Bij de onderhandelingen over een Europese kleurentelevisiestandaard in Wenen (1965) en in Oslo (I966) vertrouwden de Duitsers op hun economische potentie, de Fransen op hun politieke aanzien, macht en strategie. Terwijl de Duitsers de PAL-SECAM kwestie depolitiseerden door de nadruk te leggen op technische kwaliteit ('Made in Germany'), politiseerden de Franse actoren de controverse door in het kader van hun 'politique de grandeur' een technische en politieke alliantie te sluiten met de Sovjet-Unie en Oost-Europese landen. Deze strategie viel bij veel Europese landen in slechte aarde en leidde ertoe dat er geen uniforme Europese standaard tot stand kwam.
Ter verklaring van die mislukking gebruikt Fickers twee modellen, een 'traditioneel model' en zijn 'aanvullende interpretatie'. In het traditionele model domineren politieke en industriële krachten het standaardisatieproces omdat de drie standaarden (PAL, SECAM en NTSC) technisch en kwalitatief niet veel verschilden. Het boeiende is dat Fickers met zijn model weliswaar meer factoren, processen en dynamieken blootlegt maar de analyse van het 'traditionele' model grosso modo onderschrijft.

Fickers' poging om tot een complete en meerdimensionale analyse te komen kan geslaagd worden genoemd. De lezer kan zich daarbij geheel aansluiten bij zijn constatering dat de analyse - waarin veel concepten uit verschillende techniekhistorische en technieksociologische benaderingen opduiken - een ordenend principe, een model behoeft dat de diverse elementen verbindt en dat meer focus biedt. Opmerkelijk is wel dat in de aandacht voor transnationale dynamiek de transnationale industrierelaties onderbelicht blijven. Onduidelijk is bijvoorbeeld welke rol transnationale ondernemingen als Philips speelden in de productie en circulatie van kennis, hoe ze zich verhielden tot verschillende nationale contexten en wat hun bemiddelende rol was in de PAL-SECAM controverse. Dit geldt ook voor de rol van de Sovjet-Unie.

Hoewel de analyse getypeerd kan worden als 'productie-georiënteerd', gaat Fickers ook in op consumptie. Hij laat goed zien dat de vermeende technologische en consumptieve achterstand op de vs grotendeels een sociale constructie was die een cruciale rol speelde in de vormgeving van nationale en Europese identiteit. Minder sterk is het onderscheid dat wordt gemaakt tussen Amerikaanse en Europese consumptie en consumenten. Hierbij baseert Fickers zich op ingenieurs die zich presenteren als consumptiedeskundigen, wat illustreert dat ingenieurs en ontwerpers optraden als woordvoerders van consumenten, en dat ze op basis van die representaties techniek - en daarmee de consumptiecontext - ontwikkelden. Ook gaat Fickers voorbij aan de ontwikkeling van Europese consumptiepatronen in de context van de toen dominante sociaal-corporatistische markteconomie. 
Dat en passant ook wat mythen worden ontmaskerd inzake de heldenrollen van de geniale uitvinders Henry de France en Telefunken-ingenieur Walter Bruch, en inzake de geclaimde technische superioriteit van zowel de Franse als de Duitse standaard, zijn mooie bevindingen. Relevant is ook dat nationale techniekstijlen meer analytische handen en voeten krijgen, en dat het belang van persoonsgebonden factoren wordt getoond.

Al met al kan de conclusie niet anders zijn dan dat Fickers een prachtig boek heeft geschreven dat een belangrijke bijdrage levert aan contextualistische techniekgeschiedenis, aan mediageschiedenis en aan transnationale geschiedenis van Europa. Het is een boek dat elke zichzelf respecterende techniekhistoricus en mediahistoricus in zijn of haar bezit dient te hebben vanwege de analytische diepgang, de empirische rijkdom, de heldere stijl en de uitstekende leesbaarheid. En natuurlijk ook omdat het boek relevante en stimulerende vragen oproept voor verder onderzoek. 